\title{
三層複合中空糸膜の特徴
}

\author{
上西 理 玄
}

三菱レイヨン株式会社中央技術研究所 函739-0693 広島県大竹市御幸町 20-1

\section{Performance of Multi-Layered Hollow Fiber Membrane, MHF}

\author{
Masamoto Uenishi \\ Mitsubishi Rayon Co., Ltd. Corporate Research Laboratories \\ 20-1 Miyuki-cho, Otake, Hiroshima 739-0693, Japan
}

We have developed a Multi-Layered Hollow Fiber Membrane, MHF which has a unique structure and good gas permeability. The thin intermediate layer of the MHF is of non-porous structure and permeable to gas and impermeable to liquid. The outside and inside support layers of the MHF are made of polyolefin with a porous structure which has a porosity of about $40 \mathrm{vol} \%$. This membrane is useful for artificial lung and also deaerator to remove dissolved gas in the semiconductor pure water, developer and industrial alcohol.

Key words : gas separation / composite hollow fiber / degassing / water $/$ developer $/$ alcohol

\section{1.はじめに}

当社では，ポリオレフィンを原料とした長繊維 を製造している。この長繊維の製造過程から端を 発して，1970年代中頃に中空繊維の形態にて繊 維全体にわたり細孔容積が約 $40 \mathrm{vol} \%$ を占める多 孔質中空繊維を得ることに成功した ${ }^{1,2)}$. その後, この多孔質中空繊維（後述では, 多孔質中空糸 膜と称する）の製造をきっかけとして，膜分離 素材の研究開発が本格的にスタートし, 今日に 至っている。本稿では当社分離膜素材の研究開 発のうち, 気体分離膜に関する最近の研究成果 を紹介する。

\section{2. ポリオレフィン多孔質中空糸膜の特徵 ${ }^{3)}$}

ポリオレフィン多孔質中空糸膜を製造する賦形 技術については文献"索照されたい。この技術 によって得られる多孔質中空糸膜の特徴を以下に 記す。

(1)溶剤抽出でなく，ドライプロセスにて多孔質 化を行うので環境負荷が低く，得られる膜の 清浄度が高い.

(2)繊維軸方向にラメラ結晶とフィブリル繊維が 秩序高く配向した繊維組織の構造を有してお り, 屈曲や引っ張り変形に対して耐久性を有 する.

(3)ポリプロピレン，ポリエチレン，ポリ 4 メチ ルペンテン 1 ，ポリ弗化ビニリデンの素材に 
Table. 1 Characteristics of MHF (A), MHF (B)

\begin{tabular}{|l|c|c|c|}
\hline & Units & MHF (A) & MHF (B) \\
\hline $\begin{array}{l}\text { Support } \\
\text { Layer }\end{array}$ & & Polyethylene & Polyethylene \\
\hline $\begin{array}{l}\text { Intermediate } \\
\text { Layer } \\
\text { (Int. Layer) }\end{array}$ & & $\begin{array}{c}\text { Thermoplastic } \\
\text { Polyurethane }\end{array}$ & $\begin{array}{c}\text { Specialty Polymer } \\
\text { (Gas permeable } \\
\text { and Low swelling with } \\
\text { alcohol, ester, ether) }\end{array}$ \\
\hline $\begin{array}{l}\text { Dimensions } \\
\text { Inner diameter }\end{array}$ & $\mu \mathrm{m}$ & 200 & 185 \\
Outer diameter & $\mu \mathrm{m}$ & 280 & 300 \\
Wall Thickness & $\mu \mathrm{m}$ & 40 & 58 \\
Int. Layer & $\mu \mathrm{m}$ & 1.0 & $2 \sim 3$ \\
Thickness & & & 40 \\
\hline Properties & & & \\
Porosity & $\mathrm{Vol} \%$ & 42 & $6.0 \times 10^{-9} \sim 7.5 \times 10^{-9}$ \\
$\mathrm{O}_{2}$ Flux & $*$ & $7.5 \times 10^{-9}$ & 3.3 \\
$\mathrm{O}_{2}$ Flux / & & 2.8 & \\
$\mathrm{~N}_{2}$ Flux \\
Burst Strength & & & \\
@ 25 & $\mathrm{MPa}$ & 5.2 & 7.0 \\
\hline
\end{tabular}

${ }^{*}$ Flux; $\mathrm{cm}^{3}(\mathrm{STP}) \cdot \mathrm{cm}^{-2} \cdot \mathrm{sec}^{-1} \cdot \mathrm{Pa}^{-1}$

対して多孔質中空系膜が得られることを見出 している。これらの膜素材は，耐薬品性に優 れる。

\section{3. 三層構造からなる複合中空糸膜の開発}

当社はポリオレフィン多孔質技術を応用し，ポ リオレフィンと気体分離機能を有する薄膜素材を 溶融複合紡糸し，ついで延伸することにより“三 層複合中空系膜” (Multi-layered Hollow Fiber Membrane, MHF $)^{4,5)}$ を開発した。この膜は気 体分子の選択透過機能を追及する目的で開発され たものである.

開発した複合中空糸膜は，孔の空いていない “気体分離用均質薄膜 (中間層)”を内側，外側の 微多孔質ポリオレフィン層によって挟み込んだ構 造をしている。兰層複合中空糸膜の断面図を Fig. 1 に示す. 複合中空糸膜の気体透過特性は, この均質薄膜の気体透過特性によって支配され る. 我々は中間層素材の選定に取り組み, Table 1 に示す三層複合中空糸膜 $(\mathrm{MHF}(\mathrm{A}), \operatorname{MHF}(\mathrm{B}))$ を開発した。現在 $\operatorname{MHF}(\mathrm{A})$ は膜ジュールの形態 で製造，販売されており， MHF (B) は研究開発 段階である。いずれの三層複合中空糸膜において も，両側の支持層は，均質薄膜を機械的に補強す る役割を担っているとともに，均質薄膜の気体透

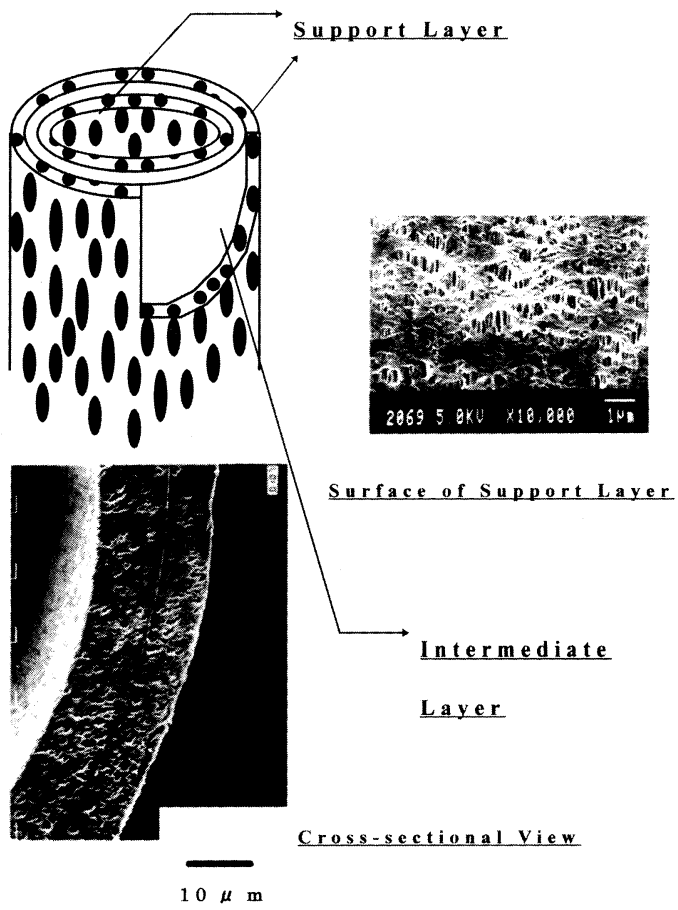

Fig. 1 Structure of MHF membrane

Table. 2 Application of MHF

\begin{tabular}{|l|l|l|}
\hline \multicolumn{1}{|c|}{ Application } & \multicolumn{1}{c|}{ Function } & \multicolumn{1}{c|}{ Effect } \\
\hline $\begin{array}{l}\text { Ultra-pure water } \\
\text { for cleaning Wafer, } \\
\text { LCD }\end{array}$ & $\begin{array}{l}\text { Removal of } \\
\text { dissolved } \mathrm{O}_{2} \text { and } \\
\mathrm{CO}_{2}\end{array}$ & $\begin{array}{l}\text { Prevention of generating } \\
\text { oxidized layer on water }\end{array}$ \\
\hline $\begin{array}{l}\text { Tap water and } \\
\text { Coolant for air } \\
\text { conditioning }\end{array}$ & $\begin{array}{l}\text { Removal } \\
\text { of dissolved } \mathrm{O}_{2}\end{array}$ & Prevention of corrosion \\
\hline $\begin{array}{l}\text { Water for } \\
\text { food processing }\end{array}$ & $\begin{array}{l}\text { Removal } \\
\text { of dissolved air and } \\
\text { contained VOC }\end{array}$ & $\begin{array}{l}\text { Prevention of oxidation } \\
\text { Improvement of safety }\end{array}$ \\
\hline $\begin{array}{l}\text { Water for } \\
\text { analytical } \\
\text { equipment }\end{array}$ & Deforming & $\begin{array}{l}\text { Improvement of accuracy in } \\
\text { quantitative analysis }\end{array}$ \\
\hline "SAKE" & $\begin{array}{l}\text { Removal } \\
\text { of dissolved } \mathrm{O}_{2}\end{array}$ & Fermentation control \\
\hline
\end{tabular}

過性を妨げることのないよう十分に連通した多孔 質構造としている.中間層は気体透過特性に優れ， ピンホールがなく, 気体のみを透過させ，液体を 透過させない薄膜である. 現在 Table 2 に示され る用途など幅広い用途展開を考えている. 


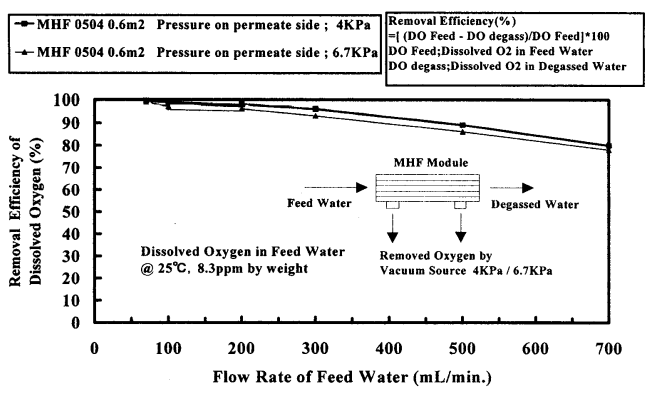

Fig. 2 Dissolved oxygen removal efficiency from feed water

\section{4. 三層複合中空糸膜の特性}

三層複合中空糸膜の特性を以下に記す。以下に おいて MHF (A) に関するデー夕は市販膜モジュ 一ルにおける代表的な性能例であり, $\operatorname{MHF}(\mathrm{B})$ に関するデー夕は研究開発で得られている基礎研 究データである.

\section{$\operatorname{MHF}(A)$}

(1)中間層は熱可塑性ウレタン樹脂であり, 低温 度でも柔軟。

$\operatorname{MHF}(B)^{6)}$

(1)中間層素材として非水系の薬液（例：アルコ ール類, 乳酸エステル類, エーテル類) に対 して膨潤の低い高分子素材を使用.

(2)薬液に対しての溶出が極めて少ない.

(3)非水系高純度薬液の脱泡, 溶存気体（酸素, 窒素など）の脱気が可能である．例として半 導体現像液中に溶解している酸素, 窒素の脱 泡，脱気や精密洗浄溶剤として用いられるイ ソプロピルアルコール (IPA), 乳酸エチル 等に溶解している窒素, 酸素の脱泡, 脱気が 可能である.

\section{5. 三層複合中空糸膜の実用性能}

\section{1. 水中の溶存酸素除去 ${ }^{6)}$}

MHF (A) を円筒状膜モジュールとした MHF 0504 (膜面積 $0.6 \mathrm{~m}^{2}$ ) の中空糸膜内側に原水 $\left(25^{\circ} \mathrm{C}\right.$ 溶存酸素濃度 $8.1 \mathrm{ppm}$ weight $)$ を供給し, 中空系膜外側圧力を真空ポンプにて $13.4 \mathrm{~K} \mathrm{~Pa}$ と

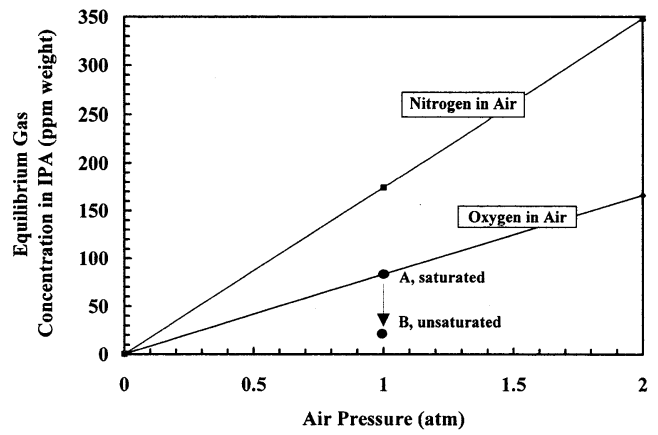

Fig. 3 Solubility of nitrogen and oxygen.

し, 膜モジュールへ single passにて通液し, 得 られる脱気処理水の溶存酸素濃度を Fig. 2 にプロ ットした。

\section{2. イソプロピルアルコール中の溶存酸素,}

\section{窒素除去 ${ }^{7}$}

IPA は工業用洗浄剤として多方面に使用されて いる．特に超音波洗浄において溶存ガスが存在す ると, キャビテーション発生時に溶存ガスが気泡 として発生し，洗浄物に付着することにより微細 部分の洗浄が行えなくなる. IPA中の溶存ガスを あらかじめ脱気しておき，これを洗浄液に使用す ることにより上記課題が改善可能と考え，以下の 基礎検討を行った. $\mathrm{MHF}(\mathrm{B})$ を用いて円筒状膜 モジュールを試作し（膜面積 $1 \mathrm{~m}^{2}$ ), IPAを中空 糸膜内側に供給し, 膜外側の圧力を $3.2 \mathrm{~K} \mathrm{~Pa}$ とし, single passにて通液し, 脱気を行った。この際 に供給するIPA はあらかじめドライ窒素でバブ リングを行い, 十分溶存酸素を追い出した後，バ ブリングを停止し，1気圧空気中の窒素，酸素に て溶解平衝へ至らしめる調整を行ったものを使用 した。溶存ガス濃度調整済みIPAをケミカルポ ンプにて中空糸膜内側へ供給し，Fig. 4 の流路に て脱気処理されたIPAを得た。脱気処理された IPA 中の酸素濃度を Fig. 4 にプロットした. Fig. 3 に空気圧力に対する酸素, 窒素の溶解度を示す. Fig. 3 において供給するIPA 中の溶存酸素はA 点 であり，脱気処理されたIPA中の溶存酸素はたと えば B 点に対応し, 飽和に至らない溶存ガス濃 度であることがわかる。 


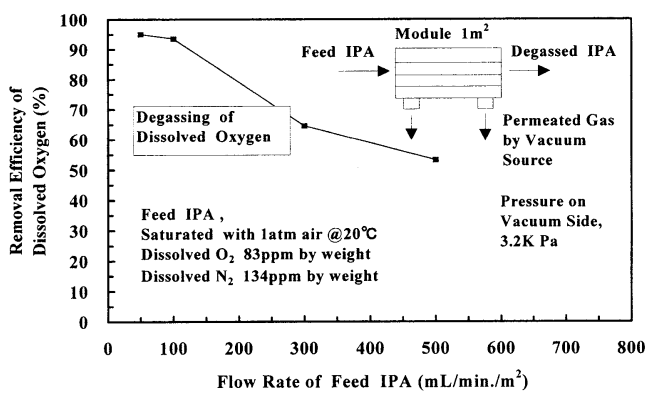

Fig. 4 Dissolved oxygen removal efficiency from feed IPA

\section{6. おわりに}

当社が開発した三層複合中空糸膜について特徴
を述べたが，今後は 1 . 薄膜の限界厚みへの挑 戦 2. 用途の開拓を目指して技術開発を行って 行きたい.

\section{文 献}

1）特開昭 52-15627（三菱レイヨン）

2) USP 4055696 (Mitsubishi Rayon Co. Ltd.)

3）加茂純 : SENI GAKKAISHI 200 (1993)

4) J. Kamo, M. Uchida, T. Hirai, H. Yoshida, K. Kamada, and T. Takemura : Artificial Organs, 14, 5, 369 (1990)

5）特許登録番号 1745065 （三菱レイヨン）

6）三層複合中空糸膜 技術資料（三菱レイヨン）

7) WO 99/17866 (1999): (Mitsubishi Rayon Co. Ltd.)

（受付 2000 年 3 月 7 日 掲載決定 3 月 23 日） 